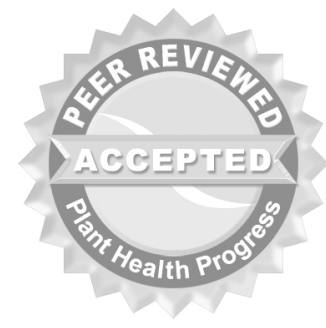

(C) 2006 Plant Management Network.

Accepted for publication 6 April 2006. Published 21 June 2006.

\title{
Illustration of Key Morphological Characteristics of Phy tophthora Species Identified in Virginia Nursery Irrigation Water
}

Elizabeth A. Bush and Erik L. Stromberg, Department of Plant Pathology, Physiology, and Weed Science, Virginia Polytechnic Institute and State University, Blacksburg 24061; and Chuanxue Hong, Patricia A. Richardson, and Ping Kong, Hampton Roads Agricultural Research and Extension Center, Virginia Polytechnic Institute and State University, Virginia Beach 23455

Corresponding author: Elizabeth Bush. ebush@vt.edu

Bush, E. A., Stromberg, E. L., Hong, C., Richardson, P. A., and Kong, P. 2006. Illustration of key morphological characteristics of Phytophthora species identified in Virginia nursery irrigation water. Online. Plant Health Progress doi: 10.1094/PHP-2006-0621-01-RS.

\section{I ntroduction}

Phytophthora diseases are commonly diagnosed on ornamental plants, but taxonomic identification to species can be intimidating. This illustrative guide is designed to aid diagnosticians in morphological identification of certain Phytophthora spp. that have been reported in irrigation and effluent water in nurseries $(3,10,11,16)$. Using both morphological and molecular methods to examine numerous isolates recovered during survey work and isolates received from colleagues in the United States and overseas, we have identified a set of diagnostic characteristics that are consistent and easy to use for morphological identification of species recovered in our survey work (3).

A range of Phytophthora spp. have been documented in diverse locations in the United States in association with effluent and recycled irrigation water at nurseries $(3,10,11,16)$. Phytophthora citrophthora, P. citricola, P. cinnamomi, P. cryptogea, P. nicotianae (= P. parasitica), P. megasperma, and P. syringae were isolated from nursery irrigation effluent in California (11); P. cinnamomi, $\mathrm{P}$. cryptogea, and P. nicotianae were isolated from nursery effluent retention basins in North Carolina (10); and P. cinnamomi, P. citricola, P. citrophthora, P. cryptogea, and P. nicotianae were isolated from nursery irrigation runoff and recycled irrigation water in Oklahoma (16). During a statewide Virginia survey for Phytophthora spp. in nursery water recycling systems, seven species of Phytophthora were recovered from one nursery (3) and a total of nine species were recovered from all locations surveyed (Hong, unpublished data). In contrast to previous surveys in other states $(10,11,16)$, P. cinnamomi and P. cryptogea were not isolated during the Virginia survey, but four other species (Phytophthora cactorum, Phytophthora drechsleri, Phytophthora palmivora, Phytophthora tropicalis) were recovered.

\section{Pathogens}

P. cactorum, P. citricola, P. citrophthora, P. drechsleri, P. megasperma, P. nicotianae (= P. parasitica), P. palmivora, P. syringae, and P. tropicalis

\section{Taxonomy}

P. tropicalis, formerly considered conspecific with P. capsici, is a recently described taxon (1). For additional taxonomic information on the other Phytophthora spp. illustrated in this publication, see CABI Sciences Databases (4) or Erwin and Ribeiro (5). 
Hosts

Phytophthora spp. are destructive plant pathogens that cause disease on numerous plants worldwide, including many herbaceous and woody ornamentals. Most of the species illustrated in this guide are commonly associated with root rot and/ or dieback on ornamental plants $(2,5,6)$.

Disease

Phytophthora root rot is the most common problem caused by Phytophthora spp. in nurseries and on ornamental plants; however, foliar blight can occur when Phytophthora inoculum is airborne or carried by splashing water to susceptible foliage (2).

\section{Symptoms}

Aboveground symptoms of Phytophthora root rot include chlorosis, stunting, and wilt. Stem tissue of affected plants may be discolored. Roots are often discolored or appear water-soaked and deficient in feeder roots. Symptoms of foliar dieback include water-soaked lesions that may progress rapidly downward in susceptible hosts, causing foliar dieback or, in severe cases, death. Woody stem tissue colonized by Phytophthora spp. often appears water-soaked and blackened (2).

\section{I solation, Culture and Long-term Storage of Phytophthora species}

Isolates recovered in the Virginia nursery water survey were recovered on $\mathrm{P}_{5} \mathrm{ARP}$ medium (see Appendix), and $\mathrm{P}_{5} \mathrm{ARP}$ amended with 50 ppm hymexazol (Tachigaren, 70\% a.i.; Sankyo Co., Tokyo) (8) to suppress faster growing members of the Pythiaceae (5). It is a good practice to include non-hymexazolamended media when attempting isolation of hymexazol-sensitive Phytophthora spp. (5) or when culturing from zoospore suspensions, since zoospore cysts are sensitive to hymexazol $(5,14)$. Additionally, we found $10 \mathrm{ppm}$ benomyl (E. I. DuPont DeNemours and Co.; Wilmington, DE) effective in suppressing growth of non-target zygomycetes (12).

Production of asexual and sexual structures is necessary for identification of Phytophthora spp. Most species require an aqueous environment to produce sporangia. In our work, isolated putative Phytophthora spp. were transferred to media amended with 5\% clarified V8 (see Appendix), which provides sterols necessary for sporulation (5). A simple and reliable method to induce sporangia production that was often used in the Virginia survey is to transfer mycelial plugs from the leading edge of cultures to Petri dishes containing soil extract (see Appendix). Cultures were then incubated at room temperature under continuous 40-watt fluorescent illumination for 1 to 4 days and observed for sporangia. Pure cultures of isolates producing sexual structures in V8-amended media after incubating in the dark were presumed homothallic. (For more information and references on production of asexual and sexual structures see Erwin and Ribeiro [5]).

Sporangia were observed with a compound microscope to determine caducity, papillation, pedicel length, etc. To determine caducity, sporulating agar plugs of mycelium were removed from aqueous culture and with the sporulating portion of the plug in contact with a microscope slide, moved briskly to dislodge sporangia. If pedicel lengths of dislodged sporangia are homogenous, this allows confidence that one is truly observing a caducous species (Fig. 1). Branching habits were observed on mycelial plugs in aqueous culture (Fig. 2). 


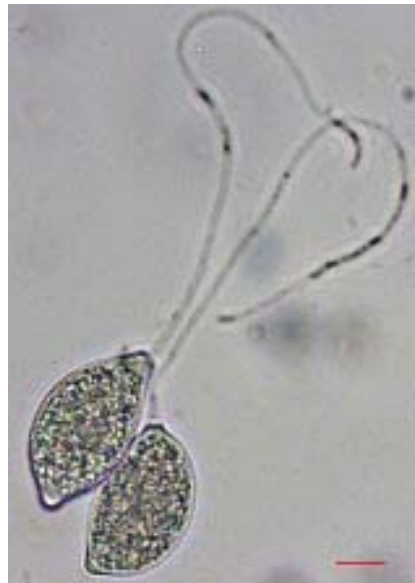

Fig. 1. Caducous sporangia and long pedicels of $P$. tropicalis. Bar $=10 \mu \mathrm{m}$.

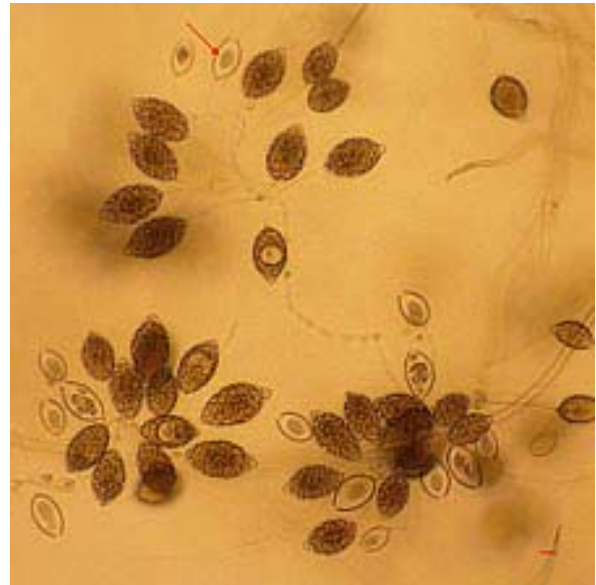

Fig. 2. Umbellate branching habit and globule (arrow) in empty sporangium of $P$. tropicalis. Bar $=10 \mu \mathrm{m}$.

For long-term storage of Phytophthora cultures, liquid nitrogen (15) is the preferred method, but many laboratories do not have this option. In our work Phytophthora isolates were stored as follows. Glass vials containing approximately $5 \mathrm{ml}$ distilled $\mathrm{H}_{2} \mathrm{O}$ and two hemp seeds were sterilized. Several 3to 5-mm agar plugs taken from the leading edge of a pure culture growing on V8 medium were transferred to the vials and after active mycelial growth appeared ( 1 to 2 days), vials were capped and sealed with Parafilm and stored in the dark at room temperature. Cultures were recovered by placing colonized agar plugs or hemp seeds on V8 culture medium. Storage in V8 medium slants covered with sterile mineral oil also works well for Phytophthora species. Isolates stored by the latter two methods typically retain viability for at least two years.

\section{Potential Pitfalls Associated with a Taxonomic Approach and I dentification of Phytophthora species Using Single-strand Conformation Polymorphism (SSCP)}

The P. megasperma isolates recovered in the Virginia survey failed to produce sexual structures both in single and dual culture (paired with both A1 and A2 mating types). Therefore, they were initially misidentified as P. cryptogea. SSCP analysis (9) of these isolates showed banding patterns consistent with type isolates of $\mathrm{P}$. megasperma (data not shown).

Identification using taxonomic keys $(5,7,13,17,18)$ is prone to error, due to sometimes variable and overlapping morphological characteristics among species. Molecular methods of identification minimize uncertainty associated with morphological identification, in addition to expediting identification. However, many diagnostic laboratories are not equipped for this type of analysis and must rely on taxonomic methods. In the Virginia survey, SSCP analysis (data not shown) (9) was used in addition to taxonomic methods and results were compared. Molecular methods may be necessary for initial identification of difficult or sterile species; however, when a positive molecular identification is made one gains reasonable confidence in subsequent identifications of the same species using morphological characteristics.

\section{Phytophthora cactorum}

P. cactorum is one of four homothallic species recovered in the survey (Table 1). P. cactorum has conspicuously papillate (i.e., apical thickening $\geq 4 \mu \mathrm{m}$ ) and caducous sporangia (Figs. 3, 4, and 5). Isolates of this species produced abundant sporangia, oogonia, and paragynous antheridia in culture media (Fig. 5). Confirming the presence of these three structures in culture media and the caducity and papillation of sporangia (i.e., apical thickening $\geq 4 \mu \mathrm{m}$ ) allows accurate identification of $\mathrm{P}$. cactorum isolates. 


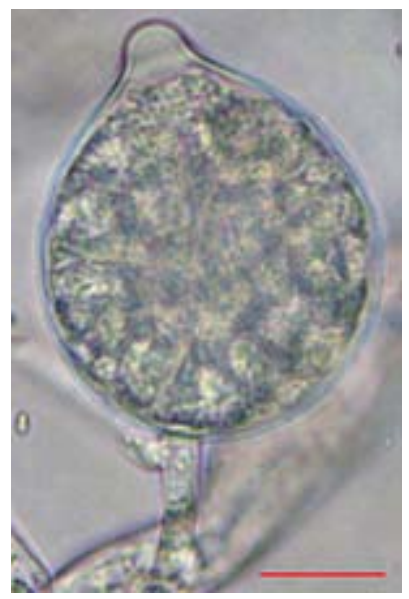

Fig. 3. Papillate sporangium of P. cactorum. Bar $=10 \mu \mathrm{m}$.

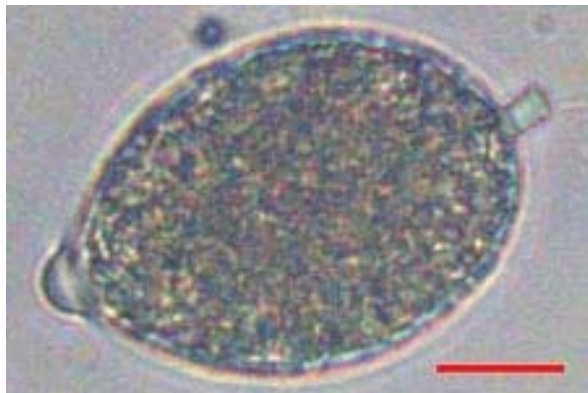

Fig. 4. Short pedicel of P. cactorum. Bar $=$ $10 \mu \mathrm{m}$.

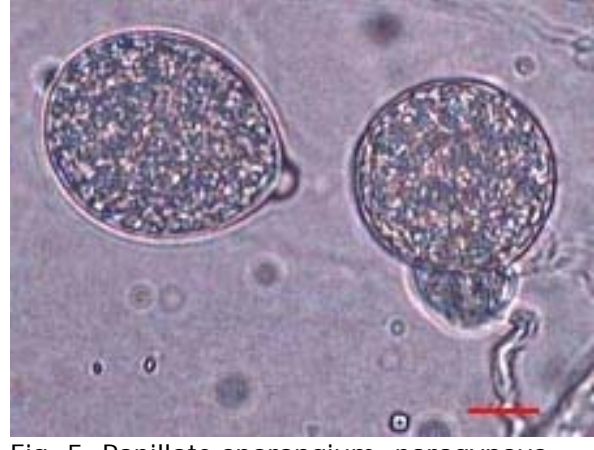

Fig. 5. Papillate sporangium, paragynous antheridium and oogonium of P. cactorum. Bar $=10 \mu \mathrm{m}$. 
Table 1. Diagnostic characteristics of Phytophthora spp. recovered from Virginia nursery water

\begin{tabular}{|c|c|c|c|c|c|}
\hline & \multicolumn{3}{|c|}{ Sporangial characteristics } & \multirow[b]{2}{*}{$\begin{array}{l}\text { Useful } \\
\text { characteristics }\end{array}$} & \multirow{2}{*}{$\begin{array}{c}\text { Water- } \\
\text { house } \\
\text { group } \\
(17)\end{array}$} \\
\hline & Papillation & Caducity & \begin{tabular}{||l} 
Pedicel \\
length
\end{tabular} & & \\
\hline \multicolumn{6}{|c|}{ Homothallic species } \\
\hline $\begin{array}{l}\text { P. } \\
\text { cactorum }\end{array}$ & Papillate ${ }^{a}$ & Caducous & Short ${ }^{\mathrm{b}}$ & $\begin{array}{l}\text { Abundant production } \\
\text { of sexual and asexual } \\
\text { structures in culture } \\
\text { media }\end{array}$ & I \\
\hline $\begin{array}{l}\text { P. } \\
\text { citricola }\end{array}$ & $\begin{array}{l}\text { Semi- } \\
\text { papillate }\end{array}$ & $\begin{array}{l}\text { Non- } \\
\text { caducous }\end{array}$ & |- & $\begin{array}{l}\text { Sporangia may have }> \\
1 \text { apex. }\end{array}$ & III \\
\hline $\begin{array}{l}\text { P. } \\
\text { megaspermad }\end{array}$ & $\begin{array}{l}\text { Non- } \\
\text { papillate }\end{array}$ & $\begin{array}{l}\text { Non- } \\
\text { caducous }\end{array}$ & |- & No growth $\geq 35^{\circ} \mathrm{C}$ & V \\
\hline $\begin{array}{l}P . \\
\text { syringae }\end{array}$ & $\begin{array}{l}\text { Semi- } \\
\text { papillate }\end{array}$ & \begin{tabular}{|l} 
Non- \\
caducous
\end{tabular} & |- & $\begin{array}{l}\text { Catenulate hyphal } \\
\text { swellings }\end{array}$ & III \\
\hline \multicolumn{6}{|c|}{ Heterothallic species } \\
\hline $\begin{array}{l}\text { P. } \\
\text { citrophthora }\end{array}$ & Papillate & $\begin{array}{l}\text { Non- } \\
\text { caducous }\end{array}$ & |- & $\begin{array}{l}\text { Sporangia often } \\
\text { irregular and/or with } \\
>1 \text { apex }\end{array}$ & II \\
\hline $\begin{array}{l}P . \\
\text { nicotianae }\end{array}$ & Papillate & \begin{tabular}{|l} 
Non- \\
caducous
\end{tabular} & $\mid-$ & $\begin{array}{l}\text { Arachnoid mycelium } \\
\text { branching habit }\end{array}$ & II \\
\hline $\begin{array}{l}\text { P. } \\
\text { palmivora }\end{array}$ & Papillate & Caducous & Short & & II \\
\hline $\begin{array}{l}\text { P. } \\
\text { tropicalis }\end{array}$ & Papillate & Caducous & Long ${ }^{f}$ & $\begin{array}{l}\text { None to little growth } \\
\text { at } \geq 35^{\circ} \mathrm{C}\end{array}$ & II \\
\hline $\begin{array}{l}\text { P. } \\
\text { drechsleri }\end{array}$ & $\begin{array}{l}\text { Non- } \\
\text { papillate }\end{array}$ & $\begin{array}{l}\text { Non- } \\
\text { caducous }\end{array}$ & |- & Growth $\geq 35^{\circ} \mathrm{C}$ & VI \\
\hline
\end{tabular}

a Apical thickening $\geq 4 \mu \mathrm{m}$.

b $<5 \mu \mathrm{m}$.

c Apical thickening $<4 \mu \mathrm{m}$.

d P. megasperma isolates recovered in our work failed to produce sexual structures in single or dual culture (paired with both A1 and A2 mating types).

e Apical thickening not apparent.

f 16 to $120 \mu \mathrm{m}$. 


\section{Phytophthora citricola}

P. citricola is a homothallic species and sporangia, oogonia, and antheridia typically develop in culture media (Table 1, Figs. 6 and 7). P. citricola was readily distinguished from the other two homothallic species (P. cactorum, P. megasperma) recovered in the Virginia survey by comparing papillation and caducity of sporangia. Sporangia of P. citricola are semi-papillate (i.e., apical thickening $<4 \mu \mathrm{m}$ ) (Fig. 6) and non-caducous, whereas sporangia of $\mathrm{P}$. cactorum are conspicuously papillate and caducous (Fig. 4). Sporangia of P. megasperma are non-papillate (i.e., apical thickening not apparent) (Fig. 8). P. citricola can be easily differentiated from the homothallic P. syringae by the absence of hyphal swellings in cultures of P. citricola.

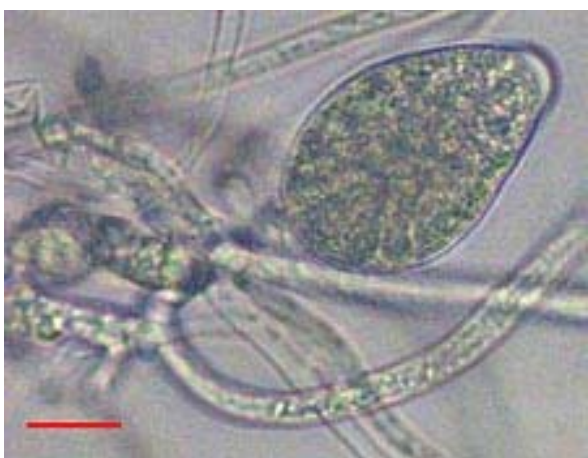

Fig. 6. Semi-papillate sporangium of $\mathrm{P}$. citricola. Bar $=10 \mu \mathrm{m}$.

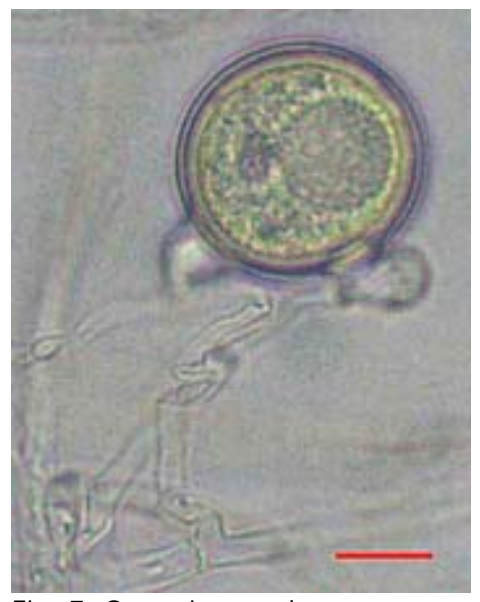

Fig. 7. Oogonium and paragynous antheridium of $\mathrm{P}$. citricola. Bar $=$ $10 \mu \mathrm{m}$.

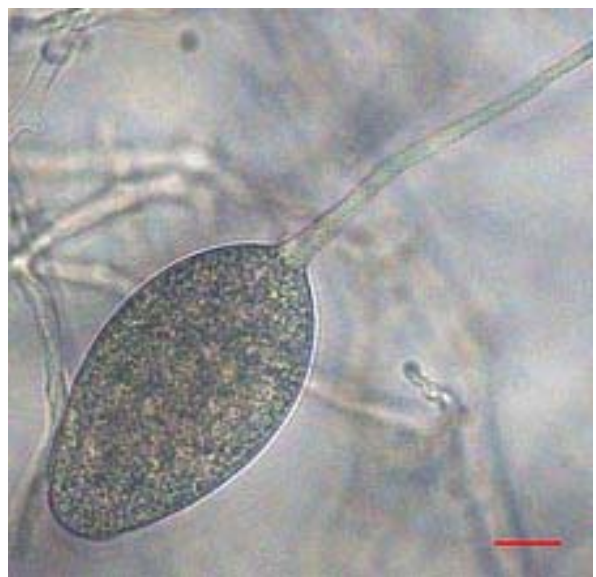

Fig. 8. Non-papillate sporangium of $\mathrm{P}$. megasperma. Bar $=10 \mu \mathrm{m}$.

\section{Phytophthora citrophthora}

P. citrophthora was commonly recovered during the Virginia survey. The heterothallic P. citrophthora can be easily differentiated from the homothallic species by the absence of sexual structures in single cultures. P. citrophthora produces papillate, non-caducous sporangia (Table 1), which are often asymmetrically shaped and may possess more than one apex (Figs. 9 and 10). P. citrophthora is easily distinguished from the heterothallic, papillate species $\mathrm{P}$. palmivora and P. tropicalis by comparing caducity of sporangia. Sporangia of $\mathrm{P}$. citrophthora are non-caducous, whereas sporangia of P. palmivora (Fig. 11) and P. tropicalis are caducous (Fig. 1). Sporangia of the heterothallic P. nicotianae, like P. citrophthora, are non-caducous. P. nicotianae can be distinguished from P. citrophthora by: (i) an arachnoid mycelial habit (Fig. 12); and (ii) more 
regular, symmetrical sporangia with a single apex (Fig. 13), in contrast to the asymmetrical sporangia or sporangia with more than one apex of $\mathrm{P}$. citrophthora.

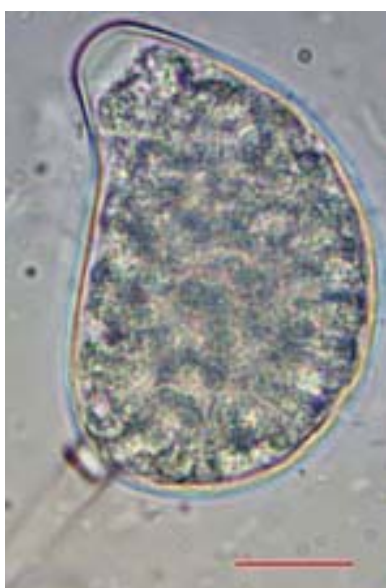

Fig. 9. Papillate, asymmetrical sporangium of P. citrophthora. Bar = $10 \mu \mathrm{m}$.

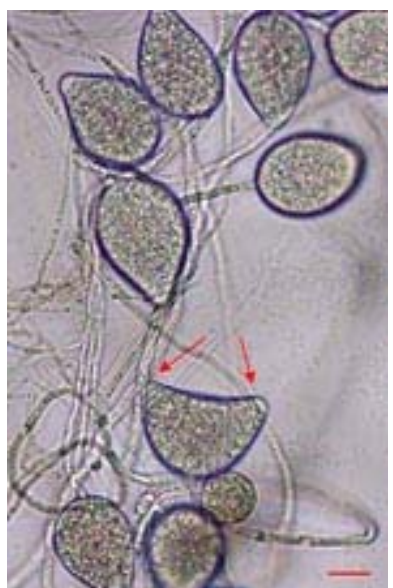

Fig. 10. Papillate sporangia and sporangium with two apices (arrows) of $P$. citrophthora. Bar $=10 \mu \mathrm{m}$.

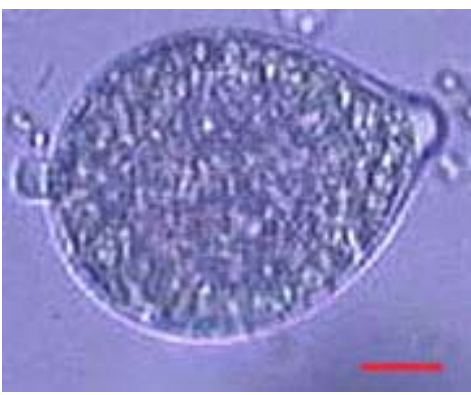

Fig. 11. Papillate sporangium and short pedicel of P. palmivora. Bar $=$ $10 \mu \mathrm{m}$.

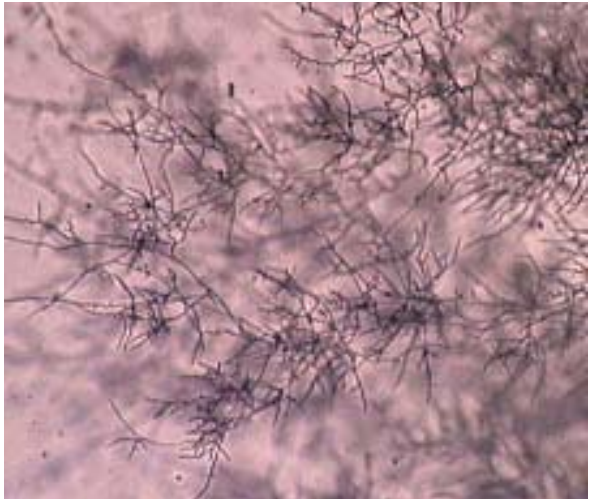

Fig. 12. Mycelium of P. nicotianae with an arachnoid branching habit.

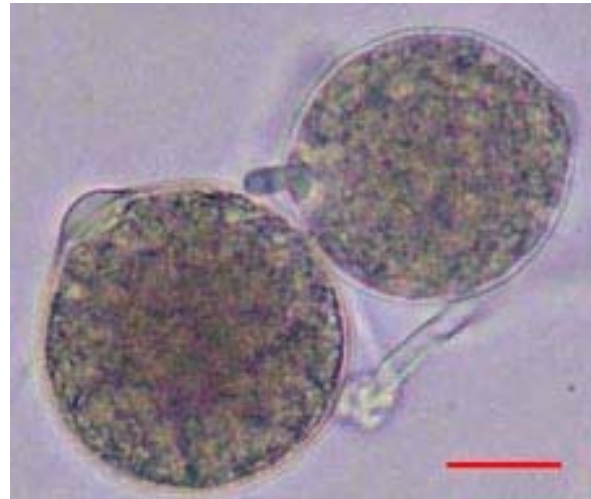

Fig. 13. Papillate sporangia of P. nicotianae. Bar $=10 \mu \mathrm{m}$. 
Phytophthora drechsleri

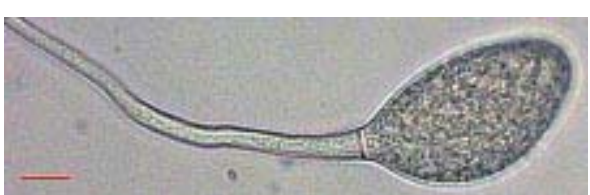

Fig. 14. Non-papillate sporangium of $\mathrm{P}$. drechsleri. Bar $=10 \mu \mathrm{m}$.
P. drechsleri was frequently recovered from nursery water. Like $P$. megasperma, P. drechsleri produces non-papillate sporangia (Table 1, Fig. 14). $\mathrm{P}$. drechsleri is morphologically identical to P. cryptogea, which was recovered from nursery recycling irrigation systems in California (11),

North Carolina (10), and Oklahoma (16). However, growth of P. drechsleri cultures at $\geq 35^{\circ} \mathrm{C}$ differentiates this species from P. cryptogea, and in our work growth or lack or growth at $\geq 35^{\circ} \mathrm{C}$ also allowed consistent separation of the nonpapillate species P. drechsleri and P. megasperma (Table 1). Gallegly reports the temperature maximum of P. megasperma at about $30^{\circ} \mathrm{C}$ (Gallegly, unpublished); however, the temperature maximum does not appear to be welldefined in the literature (5). P. drechsleri may also produce hyphal aggregates (Fig. 15).

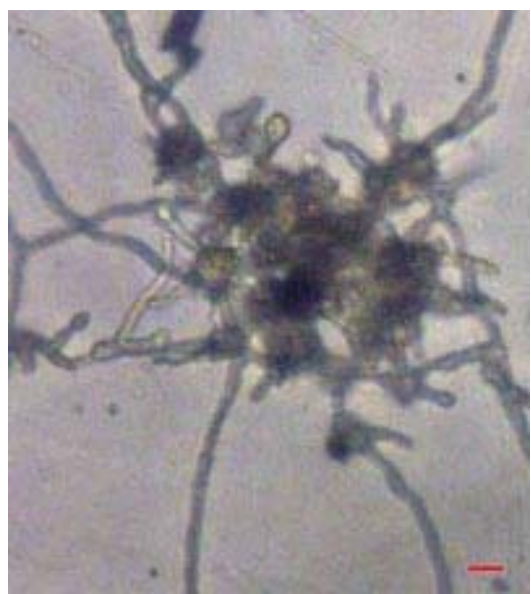

Fig. 15. Hyphal aggregate of P. drechsleri. Bar $=10 \mu \mathrm{m}$

\section{Phytophthora megasperma}

P. megasperma was frequently recovered in the Virginia survey. P. megasperma produces catenulate hyphal swellings and non-papillate sporangia (Table 1; Figs. 8 and 16). P. megasperma is homothallic; however, as noted above, isolates recovered in our survey work failed to produce sexual structures and were misidentified as P. cryptogea (3). These isolates produced a SSCP pattern typical of P. megasperma (data not shown) (9). P. megasperma was differentiated from $P$. drechsleri by its lower maximal growth temperature (< $\left.35^{\circ} \mathrm{C}\right)$.

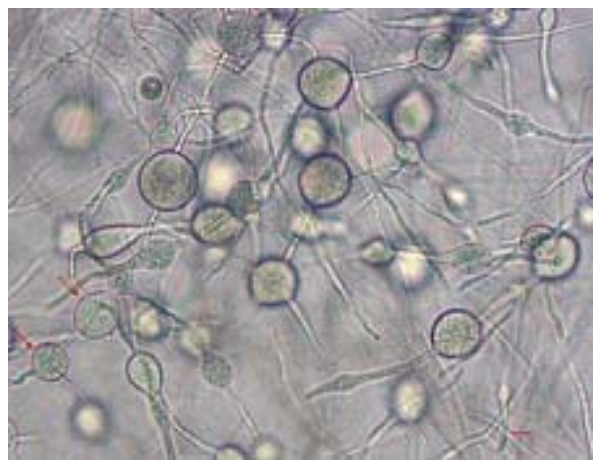

Fig. 16. Catenulate hyphal swellings

(arrows) of P. megasperma. Bar $=10 \mu \mathrm{m}$. 


\section{Phytophthora nicotianae}

Tufted colony morphology and an arachnoid branching mycelium are characteristic of P. nicotianae (Table 1, Fig. 12). Cultures of this species can often be identified with the naked eye simply by looking at colony morphology on isolation media or by a microscopic examination of the mycelium. Sporangia of P. nicotianae are non-caducous and easily differentiated from the caducous sporangia of $\mathrm{P}$. palmivora (Figs. 11 and 13).

\section{Phytophthora palmivora}

P. palmivora is one of four heterothallic species with papillate sporangia that were recovered during this survey (Table 1, Fig. 11). P. palmivora produces large chlamydospores (Fig. 17) and is easily distinguished from P. citrophthora and P. nicotianae by its caducous sporangia (Fig. 11). Comparison of sporangia pedicel length allows easy discrimination of P. palmivora and P. tropicalis. Pedicels of P. palmivora are short $(<5 \mu \mathrm{m})$ (Fig. 11), whereas pedicels of $\mathrm{P}$. tropicalis are much longer (16 to $120 \mu \mathrm{m}$ ) (Fig. 1).

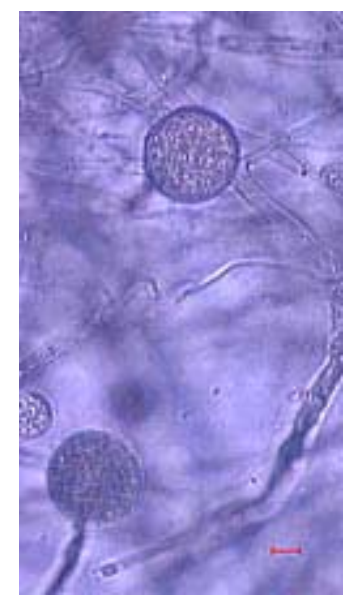

Fig. 17. Chlamydospores of

P. palmivora. Bar $=10 \mu \mathrm{m}$.

\section{Phytophthora syringae}

P. syringae is homothallic, produces semi-papillate, non-caducous sporangia, and paragynous antheridia (Table 1). This species may be confused with P. citricola. However, P. syringae produces abundant catenulate hyphal swellings (Fig. 18), whereas P. citricola produces none.

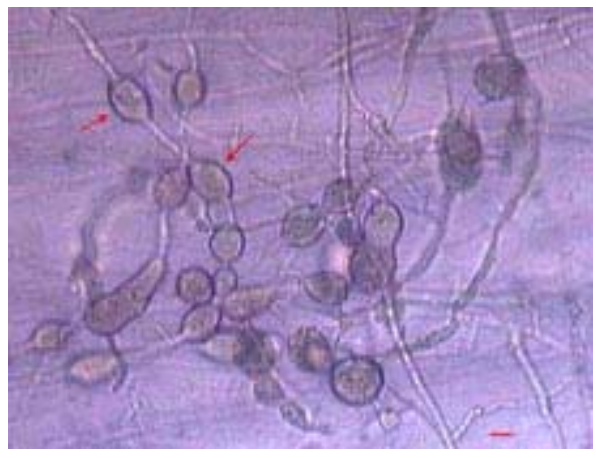

Fig. 18. Catenulate hyphal swellings (arrows) of P. syringae. Bar $=10 \mu \mathrm{m}$.

\section{Phytophthora tropicalis}

Like P. capsici and P. palmivora, P. tropicalis is heterothallic and produces papillate, caducous sporangia (Table 1, Fig. 1). Comparison of pedicel length between P. tropicalis (Fig. 1) and P. palmivora (Fig. 11) allow easy separation of these two species, as noted above. Aragaki and Uchida described P. tropicalis, 
which was previously lumped into P. capsici as a somewhat divergent group, as a new species (1). They reported sporangia of $\mathrm{P}$. tropicalis as more narrow and mostly tapered at the base and reported little to no growth at $\geq 35^{\circ} \mathrm{C}$ (1) (Fig. 1). Re-examination of the morphological characteristics and SSCP analysis (data not shown) (9) indicated that isolates previously identified in our survey work as P. capsici (3) are actually P. tropicalis. M. E. Gallegly found that isolates of P. tropicalis recovered in the Virginia survey did exhibit mostly tapered sporangial bases and had little to no growth at $\geq 35^{\circ} \mathrm{C}$, in concurrence with Aragaki and Uchida (1). Additionally he identified umbellate sympodia (Fig. 2) in aqueous cultures of P. tropicalis under light (Gallegly, unpublished data). These characteristics are in contrast to analogous characteristics of P. capsici: simple sympodial branching habit (not umbellate), sporangial bases mostly rounded, and growth at $\geq 35^{\circ} \mathrm{C}$. A large globule may be evident in sporangia of $\mathrm{P}$. tropicalis after zoospore release (Fig. 2).

\section{Acknowledgments}

We appreciate type isolates of Phytophthora spp. from Dr. Mannon E. Gallegly of West Virginia University, Morgantown, WV, Dr. Steven N. J effers of Clemson University, Clemson, SC, Dr. Mike D. Benson of North Carolina State University, Raleigh, NC, and Dr. Sharon L. von Broembsen of Oklahoma State University, Stillwater, OK. We particularly thank Dr. Gallegly for his time and patience in teaching us how to produce and examine morphological characteristics and his time and effort in double checking identities of many isolates used in this study. The expertise of Drs. Gallegly, J effers, Benson, and von Broembsen was key to the success of this project during its inception. We thank Dr. A. B. A. M. Baudoin for reviewing this manuscript.

\section{Literature Cited}

1. Aragaki, M., and Uchida, J. Y. 2001. Morphological distinctions between Phytophthora capsici and P. tropicalis sp. nov. Mycologia 93:137-145.

2. Benson, D. M., and von Broembsen, S. L. 2001. Phytophthora root rot and dieback. Pages 52-56 in: Diseases of Woody Ornamentals and Trees in Nurseries. R. K. J ones and D. M. Benson, eds. American Phytopathological Society, St. Paul, MN.

3. Bush, E. A., Hong, C. X., and Stromberg, E. L. 2003. Fluctuations of Phytophthora and Pythium spp. in components of a recycling irrigation system. Plant Dis. 87:1500-1506.

4. CABI Bioscience. 2003. IndexFungorum: Database of fungal names. Online. CABI Bioscience, Centraalbureau voor Schimmelcultures (CBS), and Landcare Research.

5. Erwin, D. C., and Ribeiro, O. K. 1996. Phytophthora Diseases Worldwide. American Phytopathological Society, St. Paul, MN.

6. Farr, D. F., Bills, G. F., Chamuris, G. P., and Rossman, A. Y. 1989. Fungi on Plants and Plant Products in the United States. American Phytopathological Society, St. Paul, MN.

7. Ho, H. H. 1981. Synoptic keys to the species of Phytophthora. Mycologia 73:705-714.

8. J effers, S. N., and Martin, S. B. 1986. Comparison of two media selective for Phytophthora and Pythium spp. Plant Dis. 70:1038-1043.

9. Kong, P., Hong, C. X., Richardson, P. A., and Gallegly, M. E. 2003. Single-strandconformation polymorphism of ribosomal DNA for rapid species differentiation in genus Phytophthora. Fungal Genet. Biol. 39:238-249.

10. Lauderdale, C. C., and J ones, R. K. 1997. Monitoring irrigation ponds for Phytophthora spp. Proc. South. Nurs. Assoc. Res. Conf. 42:225-226.

11. MacDonald, J. D., Ali-Shtayeh, M. S., Kabashima, J ., and Stites, J. 1994. Occurrence of Phytophthora spp. in recirculated nursery irrigation effluents. Plant Dis. 78:607-611.

12. Oudemans, P. V. 1999. Phytophthora spp. associated with cranberry root rot and surface irrigation water in NewJ ersey. Plant Dis. 83:251-258.

13. Stamps, D. J., Waterhouse, G. M., Newhook, F. J ., and Hall, G. S. 1990. Revised tabular key to the species of Phytophthora. CAB Intl Mycolog. Inst.

14. Tay, F. C. S., Nandapalan, K., and Davison, E. M. 1983. Growth and zoospore germination of Phytophthora spp. on P10VP agar with hymexazol. Phytopathology 73:234-240. 
15. Tooley, P. W. 1988. Use of uncontrolled freezing for liquid nitrogen storage of Phytophthora spp. Plant Dis. 680-682.

16. von Broembsen, S. L., and Wilson, S. K. 1998. Occurrence of Phytophthora spp. in nursery runoff and recycled irrigation water. Phytopathology 90:S92.

17. Waterhouse, G. M. 1963. Key to the Species of Phytophthora de Bary. Commonwealth Mycolog. Inst., Kew, Surrey, England.

18. Waterhouse, G. M., Newhook, F. J ., and Stamps, D. J . 1983. Present Criteria for Classification of Phytophthora. Pages 109-119 in: Phytophthora: Its Biology, Taxonomy, Ecology and Pathology. D. C. Erwin, S. Bartnicki-Garcia, and P. H. Tsao, eds. American Phytopathological Society, St. Paul, MN.

Appendix: Ingredients of $\mathbf{P}_{5}$ ARP, $\mathbf{V} 8$ agar, and soil extract

P $_{5}$ ARP. Difco cornmeal agar (17 g/liter); $5 \mathrm{ppm}$ pimaricin (Delvocid Instant, 50\% a.i., Gist-Brocades Fermentation Industries, Inc., Charlotte, NC); 250 ppm sodium ampicillin (Bristol Laboratories, Syracuse, NY); 10 ppm rifampicin (Sigma Chemical Co., St. Louis, MO) dissolved in $1 \mathrm{ml}$ DMSO, and 100 ppm PCNB (Terraclor, $75 \%$ a.i.).

V8 agar. For 1 liter $20 \%$ V8 agar: Add 2 gm CaCO3 to $200 \mathrm{ml} \mathrm{V8} \mathrm{juice.} \mathrm{Stir}$ for at least $20 \mathrm{~min}$. Centrifuge at 10,000 rpm for $10 \mathrm{~min}$. Transfer supernatant; discard pellet. Mix $200 \mathrm{ml}$ clarified V8 juice with $800 \mathrm{ml}$ distilled $\mathrm{H}_{2} \mathrm{O}$ and $15 \mathrm{~g}$ Difco Bacto agar (Becton Dickinson, Sparks, MD). Autoclave.

Soil extract. Add $15 \mathrm{~g}$ of sandy loam soil to 1 liter distilled H2O. Stir overnight. Allow soil particles to settle out of suspension before transfer of aqueous portion to container. Store at $4^{\circ} \mathrm{C}$. 